УДК 664.72:[664.71-11:641.1]

DOI https://doi.org/10.32838/2663-5941/2019.6-2/19

\title{
Любич В.В.
}

Уманський національний університет садівництва

Новіков В.В.

Уманський національний університет садівництва

\section{Лещенко I.A.}

Уманський національний університет садівництва

\section{ВПЛИВ ТРИВАЛОСТІ ЛУЩЕННЯ ТА ВОДОТЕПЛОВОГО ОБРОБЛЕННЯ ЗЕРНА НА ВИХІД І КУЛІНАРНУ ОЦІНКУ ПЛЮЩЕНОЇ КРУПИ ІЗ ПШЕНИЦІ ПОЛБИ}

Зерно пшениці полби повною мірою може задовольнити сучасну потребу розширення асортименту готової продукції в ніші дієтичних продуктів. Попри зростання попиту на нову сировину, ї̈ потенціал залишається не розкритим, а оптимальні технології перероблення - не розробленими. Зерно пшениці полби має високі круп'яні властивості, тому оптимізація технології його перероблення на крупу нині є актуальною. Доцільним є виготовлення крупи плющеної, оскільки вона має найвищий попит із круп'яних продуктів.

Дослідження, що наведено в статті, спрямовані на вивчення технології перероблення пшениці полби на крупу плющену. У результаті проведених досліджень встановлено, що вихід крупи плющеної найбільше залежить від тривалості лущення й пропарювання. Найбільший вихід плющеної крупи із пшениці полби отримано із зерна, яке не піддавалося лущенню, з 6-9-хвилиним пропарюванням - від 88,9 до 88,1\%, залежно від тривалості темперування.

Збільшення індексу лущення істотно змінюе вихід плющеної крупи із пшенииі полби. Наприклад, за 6-хвилинного пропарювання та відволожування вихід крупи зменшувався з 88,6 до 72,1\% за індексу лущення 11,6\%. Проте під час збільшення індексу лущення зростає ефективність пропарювання крупи.

Каша із зерна пшениці полби характеризується високою кулінарною оцінкою. За індексу лущення зерна 0-3,2\% ией показник становив 6,6-6,9 балів. Кама з високим вмістом оболонок характеризується дуже грудкуватою, з сильним хрустом $і$ занадто жорсткою консистенцією під час розжовування $і$ коричневим кольором. Збільшення індексу лущення зерна до 6,9\% підвищує кулінарну оцінку до 7,8 балів. Найвищу кулінарну оцінку 8,5-8,9 балів мала каша за індексу лущення зерна 9,9-11,6\%.

На основі аналізу отриманих результатів досліджень можна зробити висновок, що для зерна пшениці полби під час виробництва крупи плющеної необхідно проводити пропарювання впродовж 9 хв із коротким періодом відволожування (3 хв) й лущити упродовж 120 c, що відповідає індексу лущення зерна 9,9\% та має високу кулінарну оиінку - 8,5 балів.

Ключові слова: пшеничя полба, плющена крупа, лущення, пропарювання, відволожування.

Постановка проблеми. Круп’яні продукти мають постійний попит серед населення завдяки доступній ціні, легкості приготування і біологічній цінності. Значущість продукту для споживача визначається кулінарними властивостями і тривалістю приготування. Харчова цінність крупи залежить від виду культури, з якого одержано продукт, підготовчих операцій, проведених із зерном (лущення, пропарювання), і тривалості приготування, оскільки під час цього процесу значно руйнуються вітаміни. Встановлено, що для прискорення приготування крупи необхідно максимально збільшити іiі площу поверхні, а товщину - зменшити. Для одержання потрібного результату використовується процес плющення, внаслідок цього одержаний продукт має вищу проникність водою під час варіння [1, с. 28]. Підготовчі операції перед плющенням призначені забезпечити високий вихід готового продукту з відмінними кулінарними властивостями. Встановлено оптимальні параметри виробництва плющеної крупи для зерна пшениці м'якої, вівса, спельти і тритикале, проте для пшениці полби ці технологічні елементи не вивчено.

Аналіз останніх досліджень i публікацій. Конкурентоздатність серед харчових продуктів 
чимало в чому визначається якістю сировини. Важливим фактором є вміст білка, що забезпечує біологічну цінність, а також особливі фізикохімічні властивості, які зумовлюють здатність полімерів до взаємодії з іншими групами органічних сполук харчових систем [2, с. 126].

Згідно із зазначеними вимогами до сировини оптимально підходить вид плівчастої пшениці полба Triticum dicoccum (Schrank) Schuebl. Вона $€$ тетраплоїдною пшеницею з геномним складом, подібним до твердої пшениці. Пшениця полба добре росте на малородючих грунтах, холодостійка, витримує надмірне зволоження й посуху [3, с. 92]. Особлива увага до цієї культури в багатьох країнах Європи зумовлена їі придатністю до органічного землеробства, а також іiі харчовою й технологічною якістю, що дає змогу частково замінити полбою пшеницю м'яку.

Технологічний процес отримання плющених пластівців передбачає, крім звичайних операцій 3 очищення від домішок і поверхні зерна, попереднє зволожування з відволожуванням, пропарюванням, плющенням і сушінням [4, с. 17].

Лущення зерна призводить до зменшення кількості оболонок, що позитивно впливає на проникність води в крупу під час варіння; покращує консистенцію каші під час розжовування [5, с. 34].

Процес пропарювання полягає у впливі на зерно (крупу) вологи і тепла насиченою парою під тиском для спрямованої зміни їх властивостей. Проведенням процесу досягається зниження крихкості ядра із підвищенням його пластичності, що убезпечує ядро від крихкості під час лущення. Передача тепла від пари проходить за ії конденсації на поверхні ядра. Тепло і волога поступово проникає всередину ядра, тому після пропарювання проводять відволожування протягом певного періоду часу [1, с. 28].

Постановка завдання. Використання пшениці полби як джерела білка, ненасичених жирних кислот, клітковини для виробництва плющених круп $\epsilon$ перспективним. Для досягнення цілей потрібно провести вивчення впливу тривалості лущення (чинник А), режимів ВТО тривалості пропарювання (чинник В) і відволоження (чинник С) на вихід і якість крупи плющеної із зерна пшениці полби, а отже, дослідження $є$ актуальним і практично значущим.

Методика досліджень. Дослідження проводили в лабораторії кафедри технології зберігання i переробки зерна Уманського НУС «Оцінка якості зерна та зернопродуктів». Для експерименту використано зерно пшениці полби лінія LP 1152 (озима), вирощене в умовах Правобережного Лісостепу України 2018 р. Основні технологічні властивості - вміст білка 15,2\%, маса 1000 зерен 43 г, натура 780 г/л, склоподібність - 70\%. Початкова вологість - 12,2\%. Плющену крупу одержували 3 цілого і лущеного зерна пшениці полби. Маса досліджуваного зразка становила 100 г. Для лущення зерна використовували лабораторний лущильник УШЗ-1 із швидкістю обертання робочого органу 3000 об/хв. Лущення проводили 3 кроком 40 с, максимальна тривалість становила 160 c. Для оцінювання ефективності лущення зерна пшениці полби використано індекс лущення, що розраховували за формулою [6, с. 163$]$ :

$$
I_{n}=\frac{M_{3} M_{g}}{M_{3}} * 10_{0}
$$

де $\mathrm{I}_{\text {л }}$ - індекс лущення, \%;

$\mathrm{M}_{3}, \mathrm{M}_{я}$ - маса зерна до лущення та маса продукту після лущення, г.

Перед плющенням зерно пропарювали впродовж 3, 6 і 9 хв за сталого тиску насиченої пари $0,15 \pm 0,01$ МПа у лабораторному пропарнику періодичної дії (ППД-1), спроєктованого та виготовленого на кафедрі технології зберігання і переробки зерна Уманського НУС.

Відволожували крупу в термоізольованому бункері впродовж 3-9 хв. Плющення зерна проводили на плющильному верстаті марки ВПК-200. Після цього плющену крупу піддавали сушінню в сушильній установці за сталої температури $90^{\circ} \mathrm{C}$ до вологості 14 \%. Математичну обробку даних проводили методом трифакторного дисперсійного аналізу.

Вихід крупи розраховували щодо початкової маси зразка, взятого для пропарювання. Кулінарну оцінку каші з плющеної крупи проводили за 9-бальною шкалою за методикою, описаною в патенті на корисну модель «Спосіб кулінарної оцінки круп'яних продуктів із зерна тритикале $\mathrm{i}$ пшениці» № u 201507630 [7, с. 20].

Виклад основного матеріалу дослідження. У результаті проведених нами досліджень встановлено, що вихід крупи плющеної залежав від трьох досліджуваних факторів, а саме - тривалості лущення, пропарювання та відволожування (табл. 1).

Збільшення тривалості лущення (від 0 до 160 с) незалежно від чинників $B$ і $C$ істотно змінювало (у діапазоні на 14,3-26,7\%) вихід крупи плющеної $з$ пшениці полби, оскільки оболонки виконують функцію каркаса, удержуючи часточки ядра. 
Найбільший вихід крупи плющеної з цілого зерна отримано за тривалості пропарювання 9 хв і відволожування упродовж 3 хв - 88,9\%. Зменшення оболонок за тривалості лущення 160 с (індекс лущення $11,6 \%$ ) зумовило зменшення виходу крупи плющеної до 55,6\% за тривалості пропарювання 3 хв і відволожування - 9 хв.

За тривалості лущення 40-160 с (індекс лущення 3,2-11,6\%) зростала роль пропарювання зерна і відволожування.

Каша із плющеної крупи пшениці полби характеризувалась високою кулінарною оцінкою, що зумовлено високим вмістом водорозчинних білків, які покращують органолептичні показники готового продукту (табл. 2). Загальна кулінарна оцінка не змінювалась залежно від режимів водотеплового оброблення, проте покращувалась зі збільшенням тривалості лущення. Каша, зварена iз крупи, без проведення лущення зерна мала вище середньої кулінарну оцінку $-6,6$ балів, коротко- часне лущення впродовж 40 с (індекс лущення $3,2 \%$ ) неістотно підвищувало загальну кулінарну оцінку до 6,9 балів.

Загальна кулінарна оцінка змінювалася переважно через показники кольору і консистенцію каші під час розжовування. Вони мали обернену залежність від вмісту оболонок, тому найбільший індекс лущення $(11,6 \%)$ забезпечував найкращий результат кулінарної оцінки 8,9 балів.

Нами оцінено ефективність виробництва крупи плющеної за виходом крупи із загальною кулінарною оцінкою. Найбільш оптимальним $\epsilon$ пропарювання зерна 3 індексом лущення 9,9\% впродовж 9 хв із тривалістю темперування 3 хв. Це забезпечить достатній вихід крупи плющеної на рівні 77,1 \% із доброю загальною кулінарною оцінкою 8,5 балів.

Нині для споживачів важливим також є тривалість варіння каші, тому нами було визначено тривалість варіння крупи плющеної пшениці полби (рис. 1).

Вихід плющеної крупи із пшениці полби залежно

Таблиця 1 від індексу лущення та параметрів водотеплового оброблення, \%

\begin{tabular}{|c|c|c|c|c|c|c|c|c|c|c|}
\hline \multirow{4}{*}{ 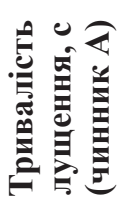 } & \multirow{4}{*}{ 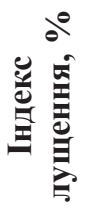 } & \multicolumn{9}{|c|}{ Тривалість пропарювання, хв (чинник В) } \\
\hline & & \multicolumn{3}{|c|}{3} & \multicolumn{3}{|c|}{6} & \multicolumn{3}{|c|}{9} \\
\hline & & \multicolumn{9}{|c|}{ Тривалість відволожування, хв (чинник С) } \\
\hline & & 3 & 6 & 9 & 3 & 6 & 9 & 3 & 6 & 9 \\
\hline 0 & 0 & 86,7 & 86,0 & 82,3 & 88,5 & 88,6 & 88,3 & 88,9 & 88,7 & 88,1 \\
\hline 40 & 3,2 & 80,8 & 77,9 & 75,4 & 85,3 & 85,9 & 84,3 & 87,3 & 87,2 & 87,1 \\
\hline 80 & 6,9 & 75,5 & 75,0 & 74,7 & 77,3 & 77,0 & 75,2 & 77,6 & 77,4 & 75,3 \\
\hline 120 & 9,9 & 70,6 & 71,1 & 65,6 & 76,3 & 76,0 & 75,3 & 77,1 & 76,4 & 74,3 \\
\hline 160 & 11,6 & 69,8 & 64,2 & 55,6 & 74,2 & 72,1 & 70,4 & 75,6 & 70,7 & 68,8 \\
\hline \multicolumn{2}{|c|}{$H I P_{05}$} & \multicolumn{9}{|c|}{$\mathrm{A}=1,4 ; \mathrm{B}=1,2 ; \mathrm{C}=1,1$} \\
\hline
\end{tabular}

Таблиця 2

Загальна кулінарна оцінка плющеної крупи із пшениці полби залежно від індексу лущення та параметрів водотеплового оброблення, бал

\begin{tabular}{|c|c|c|c|c|c|c|c|c|c|c|}
\hline \multirow{4}{*}{ 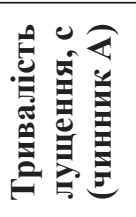 } & \multirow{4}{*}{ 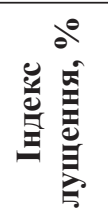 } & \multicolumn{9}{|c|}{ Тривалість пропарювання, хв (чинник В) } \\
\hline & & \multicolumn{3}{|c|}{3} & \multicolumn{3}{|c|}{6} & \multicolumn{3}{|c|}{9} \\
\hline & & \multicolumn{9}{|c|}{ Тривалість відволожування, хв (чинник С) } \\
\hline & & 3 & 6 & 9 & 3 & 6 & 9 & 3 & 6 & 9 \\
\hline 0 & 0 & 6,6 & 6,6 & 6,6 & 6,6 & 6,6 & 6,6 & 6,6 & 6,6 & 6,6 \\
\hline 40 & 3,2 & 6,9 & 6,9 & 6,9 & 6,9 & 6,9 & 6,9 & 6,9 & 6,9 & 6,9 \\
\hline 80 & 6,9 & 7,8 & 7,8 & 7,8 & 7,8 & 7,8 & 7,8 & 7,8 & 7,8 & 7,8 \\
\hline 120 & 9,9 & 8,5 & 8,5 & 8,5 & 8,5 & 8,5 & 8,5 & 8,5 & 8,5 & 8,5 \\
\hline 160 & 11,6 & 8,9 & 8,9 & 8,9 & 8,9 & 8,9 & 8,9 & 8,9 & 8,9 & 8,9 \\
\hline \multicolumn{2}{|c|}{$H I P_{05}$} & \multicolumn{9}{|c|}{$\mathrm{A}=0,3 ; \mathrm{B}=0,2 ; \mathrm{C}=0,2$} \\
\hline
\end{tabular}




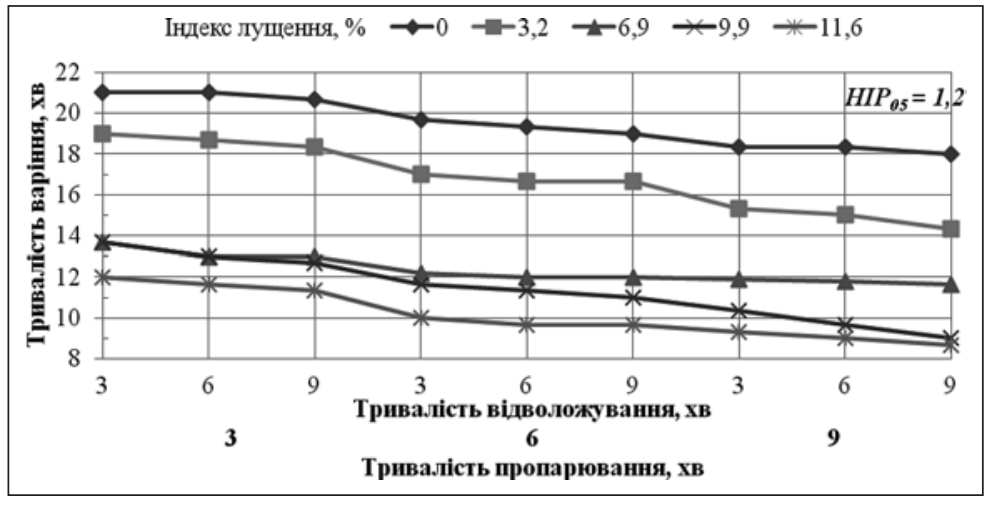

Рис. 1. Тривалість варіння плющеної крупи із пшениці полби залежно від тривалості індексу лущення, пропарювання

та відволожування, хв

Тривалість варіння каші істотно залежала від тривалості лущення і пропарювання. Різниця залежно від тривалості відволожування знаходилася в межах $\mathrm{HIP}_{05}$.

Варіння каші відбувалось від 21 до 9 хв за різної тривалості лущення, проте не залежало від режиму відволожування, але істотно зменшувалось унаслідок збільшення тривалості пропарювання. Дослідженнями встановлено [8, с. 20], що оболонки гальмують процес передачі тепла, що знижує рівень денатурації білків і клейстеризації крохмальних зерен. Тому цей показник зменшувався зі зростанням індексу лущення.

Зерно та круп'яний продукт із тривалістю лущення 40 с, що відповідало індексу $3,2 \%$, мали найдовшу тривалість варіння каші - 21-18 хв за тривалості пропарювання 3 хв. Збільшення тривалості пропарювання до 9 хв за сталого індексу лущення зумовило скорочення терміну варіння на 3-4 хв. Зростання тривалості лущення зерна істотно змінювало строк варіння крупи плющеної з пшениці полби. Наприклад, за тривалості лущення 80-160 с цей показник зменшувався від 14 до 9 хв.

За встановленого оптимального індексу лущення зерна 9,9\%, що відповідає тривалості лущення 120 с, і пропарювання упродовж 9 хв тривалість варіння каші з плющеної крупи пшениці полби становила 10 хв, що відповідає вимогам [6], де передбачено варіння крупи плющеної із зерна пшениці не більше 25 хв.

Висновки. Збільшення тривалості лущення знижує вихід крупи плющеної із зерна пшениці полби, проте збільшення тривалості пропарювання до 9 хв при цьому сприяє його підвищенню. Встановлено обернену залежність між індексом лущення i кулінарною оцінкою каші, тому під час виробництва крупи плющеної рекомендуємо використовувати крупу з пшениці полби № 1, проводити іï пропарювання впродовж 9 хв і відволожувати 3 хв із тривалістю лущення 120 с, що відповідає індексу лущення 9,9 \%. Одержана за такого рекомендованого режиму плющена крупа характеризується високою органолептичною оцінкою (8,5 балів) та низькою тривалістю варіння (10 хв).

\section{Список літератури:}

1. Возіян В. Вплив параметрів лущення та водотеплової обробки зерна на вихід і кулінарну оцінку плющеної крупи із пшениці спельти. Зернові продукти і комбікорми. 2017. Т. 17. № 1. С. 28-32.

2. Линниченко В., Егорова С. Полба - продукт здорового питания. Современные проблемы техники и технологии пищевых производств : мат-лы ХІХ Междунар. науч.-практ. конф., Барнаул : АлтГТУ, 2018. Ч. 2. С. $126-130$.

3. Бабенко Л., Рожков Р., Парій Я. та ін. Triticum dicoccum (schrank) schuebl.: походження, біологічна характеристика й перспективи використання в селекції та сільському господарстві. Вісник Харківського наиіонального аграрного університету. Серія : Біологія. Харків, 2017. Вип. 2 (41). С. 92-102.

4. Мерко А., Мельников Е., Сергеев Е., Ушакова А. Влияние подготовки зерна на качество хлопьев. Хлебопродукты. 2000. № 8. С. 17-18.

5. Любич В., Полянецька І. Якість цілої крупи із зерна спельти залежно від індексу його лущіння та водно-теплової обробки. Вісник Уманського національного університету садівництва. Первинна обробка продуктів рослинниитва. Умань, 2015. № 2. С. 34-38.

6. Крошко Г. та ін. Правила організації і ведення технологічного процесу на круп'яних заводах. Київ : Віпол, 1998. $163 \mathrm{c.}$

7. Спосіб кулінарної оцінки круп'яних продуктів із зерна тритикале і пшениці: пат. 200601 Україна. № u 2015 07630; заявл. 30.07.2015; опубл. 12.01.2016, Бюл. № 1.20 с.

8. Новіков В. Удосконалення технології виробництва круп'яних продуктів із зерна тритикале : автореф. дис. ... канд. техн. наук : 05.18.02. Київ, 2016. 20 с. 


\section{Liubych V.V., Novikov V.V., Leshchenko I.A. INFLUENCE OF THE DURATION OF DEHUSKING AND WATER HEAT TREATMENT GRAIN OBTAINING AND CULINARY EVALUATION OF WHEAT ROLLED CEREAL EMMER}

Emmer wheat grain can fully meet the current need to expand the range of finished products and in the area of dietic products. Despite the growing demand for new raw materials, its potential remains untapped and optimal processing technologies have not been developed. Emmer wheat grain has high grits characteristics, so the optimization of its processing technology is now a priority. It is advisable to make peeled grits because it has the highest demand among grits products.

The research, presented in the article, is aimed at studying the technology of emmer wheat processing into peeled grits. Studies have shown that the yield of peeled grits mostly depends on the time of peeling and steaming. The highest yield of peeled grits of emmer wheat was obtained from non-peeled grain, with 6-9 minutes steaming - from 88.9 to $88.1 \%$, depending on the time of tempering.

An increase in the peeling index highly influences the yield of peeled grits from emmer wheat. Thus, for 6 minutes of steaming and moistening, the grits yield decreased from 88.6 to $72.1 \%$ with a peeling index of $11.6 \%$. However, as the peeling index increases, the efficiency of grits steaming increases.

Emmer wheat porridge is characterized by high culinary assessment. For the grain peeling index of 0-3.2\%, this indicator was 6.6-6.9 points. The high-peel content porridge is characterized by a very lumpy, heavy crunchy and too stiff consistency during chewing and by brown colour. Increasing the grain peeling index to $6.9 \%$ raises the culinary assessment to 7.8 points. The highest culinary assessment of $8.5-8.9$ points has porridge with a grain peeling index of $9.9-11.6 \%$.

Based on the analysis of the obtained results, it can be concluded that for emmer wheat grain during the peeled grits production, it is necessary to steam for 9 min with a short period of moistening ( $3 \mathrm{~min}$ ) and peel for $120 \mathrm{~s}$, which corresponds to the grain peeling index of $9.9 \%$ and has a high culinary assessment -8.5 points.

Key words: emmer, flattened groats, exfoliation, steaming, softening. 